\title{
A pilot study of acotiamide hydrochloride hydrate in patients with detrusor underactivity
}

\author{
This article was published in the following Dove Press journal: \\ Research and Reports in Urology \\ 8 May 2015 \\ Number of times this article has been viewed
}

\author{
Koichi Sugimoto' \\ Takahiro Akiyama ${ }^{2}$ \\ Nobutaka Shimizu ${ }^{3}$ \\ Naoki Matsumura' \\ Taiji Hayashi' \\ Tsukasa Nishioka' \\ Hirotsugu Uemura ${ }^{3}$ \\ 'Department of Urology, Sakai \\ Hospital, Kinki University Faculty \\ of Medicine, Sakai, Osaka, Japan; \\ ${ }^{2}$ Department of Urology, Sakai- \\ Onshinkai Hospital, Sakai, Osaka, \\ Japan; ${ }^{3}$ Department of Urology, \\ Kinki University Faculty of Medicine, \\ Osaka-Sayama, Osaka, Japan
}

Aim: To investigate the clinical efficacy of acotiamide hydrochloride hydrate in patients with detrusor underactivity.

Methods: We measured the post-void residual urinary volume in 19 patients with underactive bladders. All these patients had been under treatment with distigmine bromide and were prescribed acotiamide hydrochloride hydrate at a dose of $100 \mathrm{mg}$ three times daily for 2 weeks.

Results: Compared with the post-void residual urinary volume value at baseline $(161.4 \pm 90.0 \mathrm{~mL})$ a statistically significant reduction was observed at the end of treatment $(116.3 \pm 63.1 \mathrm{~mL})$ $(P=0.006)$. The drug was generally well tolerated by the majority of patients.

Conclusion: Maybe, acotiamide hydrochloride hydrate showed clinical efficacy in patients with underactive bladders and may, therefore, be used alternatively in patients who do not respond sufficiently to distigmine bromide.

Keywords: acotiamide hydrochloride hydrate, distigmine bromide, underactive bladder, detrusor underactive

\section{Introduction}

Detrusor underactivity (DU) is defined as a contraction of reduced strength and/or duration, resulting in prolonged bladder emptying and/or failure to achieve complete bladder emptying within a usual time span. ${ }^{1}$ Some of the established causes of DU are neurogenic or myogenic in nature or due to aging and medication side effects. ${ }^{2}$ In humans, distigmine bromide increases the urinary flow rate through improved detrusor contractility in patients with DU. ${ }^{3}$ But this drug may cause a cholinergic crisis. As this adverse event may be lethal, we hesitate using this drug.

AChE inhibitors are also used for the treatment of myasthenia gravis as acetylcholine is required for the contraction of muscle fibers. ${ }^{4}$ Acotiamide appears to exert an antagonistic effect on muscarinic M1, M2, and M3 receptors and thereby inhibit the negative feedback system by blocking muscarinic auto receptors that regulate acetylcholine release. ${ }^{5,6}$ So, we think this drug might be effective in patients with DU.

\section{Methods}

\section{Subjects}

This was an open, non-randomized study. The protocol was approved by the Ethics Committee of Sakai-Onshinkai Hospital. Informed consent was obtained from patients before the start of the study. The study was not placebo controlled, however, a placebo effect could not be entirely excluded.
Department of Urology, Sakai Hospital, Kinki University Faculty of Medicine,

2-7-I Harayamadai, Minami-ku, Sakai,

Osaka 590-0132, Japan

Email sugimo5I@med.kindai.ac.jp 
The subjects of the present study were patients with clinical DU who received outpatient treatment at the Department of Urology of Sakai-Onshinkai Hospital between July 2013 and March 2014. The patients underwent gastrointestinal fiberscopy to rule out the possibility of gastric cancer.

\section{Medication}

The recommended dosage of acotiamide is $100 \mathrm{mg}$ taken three times daily prior to a meal.

\section{Study design}

The medication was switched from distigmine bromide to acotiamide, and post-void residual (PVR) urinary volume at 2 weeks after switching was compared with baseline value in each patient.

\section{Statistical analysis}

The mean \pm standard deviation was calculated. A paired Student's $t$-test was used to analyze the difference in PVR urinary volume value. Statistical significance was set at $P<0.05$.

\section{Results}

Nineteen patients consented to participate in the study and have their PVR urinary volume measured before and after acotiamide treatment (Table 1). The mean age of the patients was 75.7 years (range: 61-89). There were eleven men and eight women. According to symptoms (slow stream, hesitancy, straining, etc), 16 had a neurogenic bladder ( $\mathrm{NgB})$, two had an $\mathrm{NgB}$ and benign prostatic hyperplasia, and one had an $\mathrm{NgB}$ and prostatic cancer. PVR urinary volume changed from $161.4 \pm 90.0 \mathrm{~mL}$ at baseline to $116.3 \pm 63.1 \mathrm{~mL}$ at 2 weeks post-treatment $(P<0.05)$ (Figure 1). In eleven

\section{Table I Patient characteristics}

\begin{tabular}{ll}
\hline Number of patients & 19 \\
Sex (male/female) & $11 / 8$ \\
Mean age (range) & 75.7 (6I-89) \\
$\mathrm{NgB}$ (male) & 8 \\
$\quad$ Mean prostatic volume $\left(\mathrm{cm}^{3}\right)$ & 17.3 \\
$\mathrm{NgB}$ and BPH (male) & 2 \\
$\quad$ Mean prostatic volume $\left(\mathrm{cm}^{3}\right)$ & 42.5 \\
$\mathrm{NgB}$ and prostatic cancer $\left(\mathrm{male}^{3}\right)$ & $\mathrm{I}$ \\
$\quad$ Mean prostatic volume $\left(\mathrm{cm}^{3}\right)$ & 8 \\
$\mathrm{NgB}$ (female) & 8 \\
Concomitant drug & \\
$\quad$ Tamsulosin hydrochloride & 5 \\
$\quad$ Naftopidil & $\mathrm{I}$ \\
Silodosin & 5 \\
Urapidil & 8 \\
\hline
\end{tabular}

Abbreviations: $\mathrm{NgB}$, neurogenic bladder; $\mathrm{BPH}$, benign prostatic hyperplasia.
Figure I PVR urinary volume changed from $161.4 \pm 90.0 \mathrm{~mL}$ at baseline to $116.3 \pm 63.1 \mathrm{~mL}$ at 2 weeks $(P<0.05)$

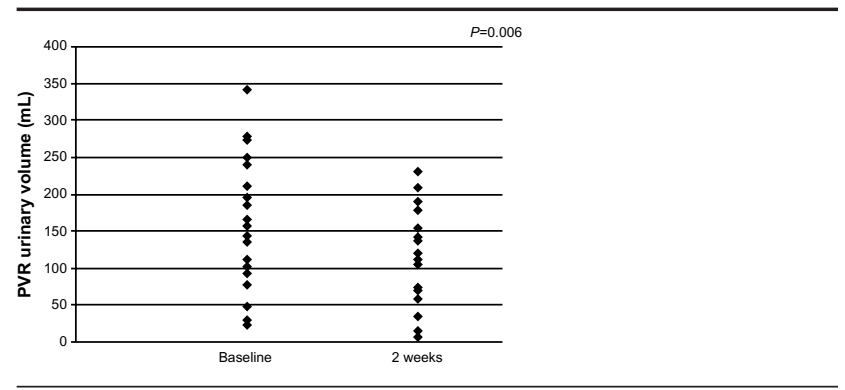

Abbreviation: PVR, post-void residual.

men, PVR urinary volume decreased from $170.4 \pm 109.8 \mathrm{~mL}$ at baseline to $115.9 \pm 74.4 \mathrm{~mL}$ at 2 weeks $(P<0.05)$. In eight women, PVR urinary volume decreased from 149.1 \pm 57.6 $\mathrm{mL}$ at baseline to $116.8 \pm 48.3 \mathrm{~mL}$ at 2 weeks $(P<0.05)$. Thus acotiamide was effective in both men and women.

\section{Discussion}

DU has the advantage of a published urodynamic definition that relates to the abnormalities underlying symptoms. However, the term DU, by virtue of vagueness of its clinical characterization based on symptoms, is unlikely to mean as much to patients and clinicians as overactive bladder. ${ }^{7}$

DU is a condition often misdiagnosed until a large PVR urinary volume is noted. Patients with DU are at a potential risk of developing chronic renal failure due to chronic urinary retention, if they are not promptly diagnosed. These patients usually present with voiding difficulties, recurrent urinary tract infections or overflow incontinence.

In clinical practice, $\alpha$-blockers are widely used to attain urethral relaxation. If despite treatment with $\alpha$-blockers difficulty with urination persists, distigmine bromide, an AChE inhibitor, is often used. ${ }^{3,8,9}$

Acotiamide hydrochloride is effective in patients with functional dyspepsia. ${ }^{10}$ Moreover, as this drug has bladder selectivity (ZERIA Pharmaceutical Co, Ltd, unpublished data), we thought that acotiamide hydrochloride would be more effective than distigmine bromide in patients with DU. As expected, acotiamide hydrochloride decreased PVR urinary volume in the present study and thus the drug may be a promising one for treating DU.

Despite the very small number of patients included in this study and its short duration, we could attain a significant decrease of PVR urinary volume using acotiamide. Moreover, none of the patients developed an adverse event as serious as cholinergic crisis. The results of this study indicate that acotiamide may be as effective as distigmine bromide in 
decreasing PVR urinary volume. We think that a prospective randomized controlled study should be done in the near future. And we must expand on the mechanism as to how this drug really works.

\section{Disclosure}

The authors declare that they have no conflicts of interest.

\section{References}

1. Abrams P, Cardozo L, Fall M, et al. The standardisation of terminology in lower urinary tract function: report from the standardisation sub-committee of the International Continence Society. Urology. 2003;61(1):37-49.

2. Chancellor MB, Kaufman J. Case for pharmacotherapy development for underactive bladder. Urology. 2008;72(5):966-967.

3. Bougas DA, Mitsogiannis IC, Mitropoulos DN, et al. Clinical efficacy of distigmine bromide in the treatment of patients with underactive detrusor. Int Urol Nephrol. 2004;36(4):507-512.

4. Romi F, Gilhus NE, Aarli JA. Myasthenia gravis: clinical, immunological, and therapeutic advances. Acta Neurol Scand. 2005;111(2): 134-141.
5. Doi Y, Murasaki O, Kaibara M, et al. Characterization of functional effects of Z-338, a novel gastroprokinetic agent, on the muscarinic M1, M2, and M3 receptors expressed in Xenopus oocytes. Eur J Pharmacol. 2004;505(1-3):31-35.

6. Yoshii K, Hirayama M, Nakamura T, et al. Mechanism for distribution of acotiamide, a novel gastroprokinetic agent for treatment of functional dyspepsia, in rat stomach. J Pharm Sci. 2011;100(11):4965-4973.

7. Osman NI, Chapple CR, Abrams P, et al. Detrusor underactivity and underactive bladder: a new clinical entity? A review of current terminology, definitions, epidemiology, aetiology, and diagnosis. Eur Urol. 2014;65(2):388-398.

8. Barendrecht MM, Oelke M, Laguna MP, Michel MC. Is the use of parasympathomimetics for treating an underactive urinary bladder evidence-based? BJU Int. 2007;99(4):749-752.

9. Hameed A, Charles TJ. Cholinergic crisis following treatment of postoperative urinary retention with distigmine bromide. Br J Clin Pract. 1994;48(2):103-104.

10. Matsueda K, Hongo M, Tack J, Aoki H, Saito Y, Kato H. Clinical trial: dose-dependent therapeutic efficacy of acotiamide hydrochloride (Z-338) in patients with functional dyspepsia - $100 \mathrm{mg}$ t.i.d. is an optimal dosage. Neurogastroenterol Motil. 2010;22(6):618-e173.
Research and Reports in Urology

\section{Publish your work in this journal}

Research and Reports in Urology is an international, peer-reviewed, open access journal publishing original research, reports, editorials, reviews and commentaries on all aspects of adult and pediatric urology in the clinic and laboratory including the following topics: Pathology, pathophysiology of urological disease; Investigation and treatment of

\section{Dovepress}

urological disease; Pharmacology of drugs used for the treatment of urological disease. The manuscript management system is completely online and includes a very quick and fair peer-review system, which is all easy to use. Visit http://www.dovepress.com/testimonials.php to read real quotes from published authors. 